\title{
Industrial Life-Cycle and the Development of the Russian Tourism Industry
}

\author{
Marina Sheresheva ${ }^{1, *}$, Lilia Valitova ${ }^{1}$, Maria Tsenzharik ${ }^{2}$ and Matvey Oborin ${ }^{3,4}$ \\ 1 Department of Economics, Lomonosov Moscow State University, 119991 Moscow, Russia; lvalit@gmail.com \\ 2 Department of Economics, St. Petersburg State University, 199034 St. Petersburg, Russia; \\ m.tsenzharik@spbu.ru \\ 3 Department of Accounting and Finance, Perm Institute (Branch) of the Plekhanov Russian University of \\ Economics, 614070 Perm, Russia; matvey_uk@rambler.ru \\ 4 Department of Economics and Information Technologies, Perm State Agro-Technological University Named \\ after Academician D. N. Pryanishnikov, 614990 Perm, Russia \\ * Correspondence: sheresheva@econ.msu.ru
}

Received: 20 April 2020; Accepted: 1 June 2020; Published: 3 June 2020

check for updates

\begin{abstract}
The purpose of the study presented in the paper is to highlight the influence of the microeconomic factors related to the evolutionary stage of the industry's life cycle on the industry dynamics. The authors use the example of the Russian tourism industry to show that microeconomic factors are important, along with the macroeconomic, market, and demand characteristics external to the industry. Data mining was applied to obtain data from the industrial enterprise database and Rostourism official documents since there are no regular Russian statistics on firms' exit and new entry. The authors used annual ranked listing of firms by their revenues to determine the structural indicators of the industry. The results confirm that it is important to consider not only the demand and macroeconomic indicators, which are external risks in relation to the industry, but also the internal processes at the different stages of the product cycle. In a sufficiently long period, the influence of microeconomic indicators may be no less strong than the business factors of financial risk. One should take this into consideration in econometric modeling on long time-series.
\end{abstract}

Keywords: tourism; market structure; market concentration; competitive environment; crises; Russia

\section{Introduction}

The dynamics of the tourism industry development is usually illustrated by such indicators as traffic volumes, tourist flow, volume of rendered services (in value terms), and the number of destinations served (Song et al. 2012; Javid and Katircioglu 2017; Soh et al. 2019). The dynamics of the tourist flow is greatly influenced by the demand side factors and the market (macroeconomic) conditions as a whole (Massidda and Etzo 2012; Song et al. 2012; Morley et al. 2014). This approach, which pays great attention to external shocks, can be effective in describing short-term fluctuations, but does not give an answer to what a long-term trend in the development of the tourism industry looks like. To describe industry dynamics, it is necessary to combine an approach that performs exogenous factors and endogenous models of the life cycle of the industry. The idea of using the life cycle concept was also used in the tourist area life cycle (TALC) model (Butler 1980, 2006; Lagiewski 2006). This model is one of the most widely used conceptual and managerial frameworks to be employed in the tourism area (Baum 1998). However, the indicators used in TALC models are always demand-driven. These are the number and types of tourists that determine the development trends of a particular territory.

Yet, another view of industry dynamics is also possible. From the industrial organization theory point of view, industry development is non-linear (Armstrong and Porter 2007). Each market in its 
development goes through several stages-from the emergence of the industry to its maturity and transformation (Klepper 1997; Peltoniemi 2011). The market dynamics, in addition to performance indicators (sales, output, demand characteristics, etc.), are determined by the number of agents active in the market, the relative size of firms (i.e., market concentration), etc. (Dosi and Nelson 2010; Amir and Lazzati 2011). It is also important to take into account the accompanying processes of industry "demography" - indicators of firms' entry into the market and firms' exit from the market (Frenken et al. 2015; Clementi and Palazzo 2016).

In turn, the dynamics of the entry-exit-total number of firms is determined by existing and changing industry administrative barriers (Jelili and Goaied 2010; Lábaj et al. 2018), such as requirements for the size of the initial capital, for financial provision, for insurance of activities, as well as "technical" restrictions connected with scale and scope economy and minimal effective output. Technological factors, together with characteristics of the demand for tourism services, lead to a larger or smaller number of firms that conduct their activities in the market.

As an additional factor explaining entry, exit, and survival, we can consider the market development stage (Garay and Cánoves 2011). As the market evolves from infancy to maturity, the rate of growth in demand and the minimum efficient size of firm are both likely to change. The sources of technical change and innovations shift between incumbent firms and inventors external to an industry (Agarwal and Gort 1996). The more mature market is, the less is the role of the learning-by-doing factor, as a large number of information sources appear (professional research, conferences, and other opportunities to exchange experience). In the labor market, industry specialists appear who are ready to share experience and offer their services. All these factors, ceteris paribus, reduce the dependence of a firm's survival on its age and experience, though work experience in tourism or related sectors is preferred, especially for micro-firms survival (Brouder and Eriksson 2013).

Since the tourism industry was not in the focus of economic research until recent decades (Stabler et al. 2009), there are many lacunes, including issues of the market structure and industry life cycle, as well as the influence of microeconomic factors on the industry dynamics. As to Russian tourism, little research has been undertaken on this topic, though there are some publications discussing different aspects of the market development (Koenker 2003; Algieri 2006; Dimanche and Andrades 2015; Sheresheva and Kopiski 2016; Zaitseva et al. 2016; Andrades and Dimanche 2017; Frolova et al. 2017; Gudkov et al. 2018; Sheresheva 2018; Chkalova et al. 2019).

The main aim of the work presented in the paper was to show, using the example of the Russian tourism industry, how microeconomic factors related to the evolutionary stage of the industry's life cycle influence the industry dynamics along with the macroeconomic, market, demand characteristics external to the industry.

\section{Materials and Methods}

In economic theory, there are many approaches and models related to the life cycle of organizations (Quinn and Cameron 1983; Jawahar and McLaughlin 2001; Lester et al. 2003). Most of them are based on the hypothesis that the same internal mechanisms operate in the business world as in the regulation of ecosystems, which are based on competition for resources (Brock and Xepapadeas 2002; Freiling and Baron 2017). There are very few quantitative studies on this subject since the study of industry dynamics is not that easy due to the need to analyze long rows of historical data.

As a rule, the life cycle of industries is counted for 30-50 years. In recent years, there has been a downward trend in both the average industry life cycle duration and the average firm age. Thus, the companies on the first Standard and Poor's index of 90 major US companies created in the 1920s stayed in the list for an average of 65 years. Taking into account the average anticipated tenure of a company on the S\&P 500 in 1998, Foster and Kaplan (2001) predicted that no more than a third of today's major corporations will survive in an economically important way over the next quarter-century (Foster and Kaplan 2001). In accordance with the innovation consulting firm "Innosight" data and forecast on corporate longevity briefing “2018 Corporate Longevity Forecast: Creative Destruction is 
Accelerating", the 33-year average tenure of companies on the expanded S\&P 500 in 1964 narrowed to 24 years by 2016 and is forecast to shrink to just 12 years by 2027 (Scott et al. 2018).

A good example of an industry dynamics study is the empirical work conducted by Agarwal and Gort (1996). The authors examine the entry, exit, and survival of firms from twenty-five industries, from the production of antibiotics to gas turbines, depending on the industry life cycle stage. The analysis of stage of development of a product market starts with the stylized facts developed in Gort and Klepper (1982). The industry life cycle is divided into five stages, based on the rate of net input (changes in the number of firms in the market) (Figure 1). Stage 1 corresponds to the initial period when there are only a few sellers. Stage 2 is the stage of a large increase in the number of sellers; it consists of the initial phase of net input acceleration, followed by a period of deceleration. Stage 3 is a transitional plateau when the number of sellers in the market stabilizes. Stage 4 is a period of negative net entry that takes place for the vast majority of markets; it may also be subdivided into phases of acceleration and deceleration in negative net entry. Stage 5 corresponds to the market maturity and, at the same time, to the emergence of a new market based on fundamentally new production technologies for a product or service.

\section{Entry, exit and number of firms across stages,}

from Agarwal, Gort (1996)

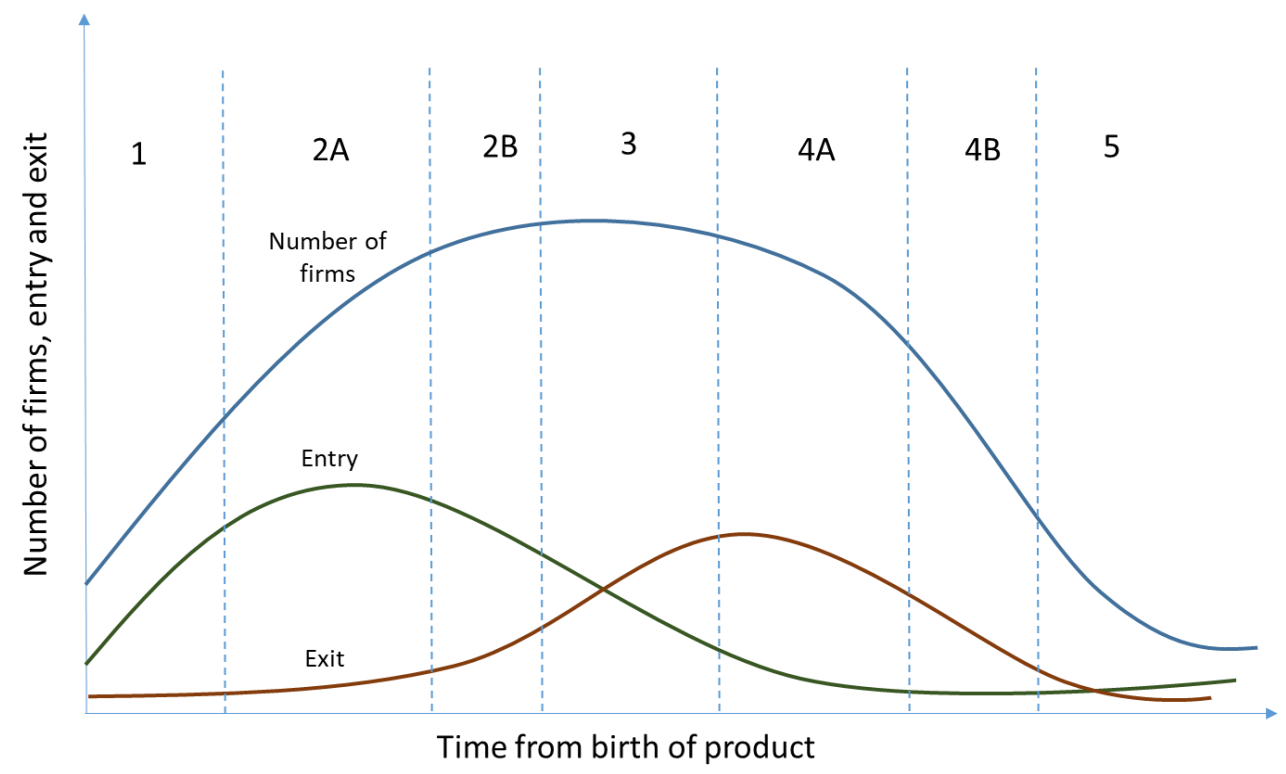

Figure 1. Entry, exit and number of firms across the industry life cycle stages.

In the tourism industry, at the first stage, when firms do not have accumulated experience and volumes that can achieve significant economies of scale, barriers to entry are not high and are associated only with administrative requirements for capital adequacy and liquidity in case a significant number of customers choose return purchased vacation packages (travel services) back. At stage 2A, which, obviously, describes the heyday of the market and the arrival of a large number of tour operators in the industry, older firms with learning-by-doing gain an advantage over younger firms. In addition, large tour operators show economies of scale associated with lower unit costs per tourist. If we analyze the size of firms and their market share, then at stage $2 B$, with a decrease in the number of new firms, market concentration begins to increase, that is, the share of several of the largest firms. At this stage, the market rarely remains competitive and becomes an oligopoly or model of a dominant firm with a competitive fringe.

Data mining was the most time-consuming part of this work, as there are no regular statistics on firms' exit and new entry. We used information from the officially published documents of the Federal Agency for Tourism in the Russian Ministry of Economic Development (Rostourism) which provides 
monthly lists of firms excluded and included in the register of tourist firms. Similarly, we obtained firms" "birth" and "death" annual data from the industrial enterprise database ( SPARK-Interfax» ${ }^{1}$ ), according to registration and liquidation date.

We used annual ranked listing of firms by their revenues to determine the structural indicators of the industry, namely the share of four largest firms and the Herfindahl-Hirschman Index-a well know economic concentration measure, used also to measure the concentration of tourism activity (Petković et al. 2016; Fernandes et al. 2020). Our assumption was that the share of firm's revenue in the industry's total revenue is equal to the firm's market share, though some firms may have a diversified business.

As we have mentioned above, there was a problem with both sources of information related to the reasons for firm's exclusion from the register and inclusion in the register-this may occur for a reason unrelated to true liquidation, but to the inability to meet the requirements of the regulator to provide financial statements and financial guarantees in time. In this case, firms are re-registered and we get re-entry and re-exit data. We have also admitted that this phenomenon is not regular. In addition, failure to meet regulatory requirements may indicate the inability to overcome administrative barriers, etc.

The data on which we relied in our analysis are presented in Table 1. We combined data from two sources of statistical information (Rostourism and Register of industrial enterprises). Firms' "entry" is estimated as the number of records of new firms in the industry, while "exit" on the basis of firms' liquidation records. We calculated the HHI and concentration index for the 4 largest firms (CR-4).

Table 1. Data description.

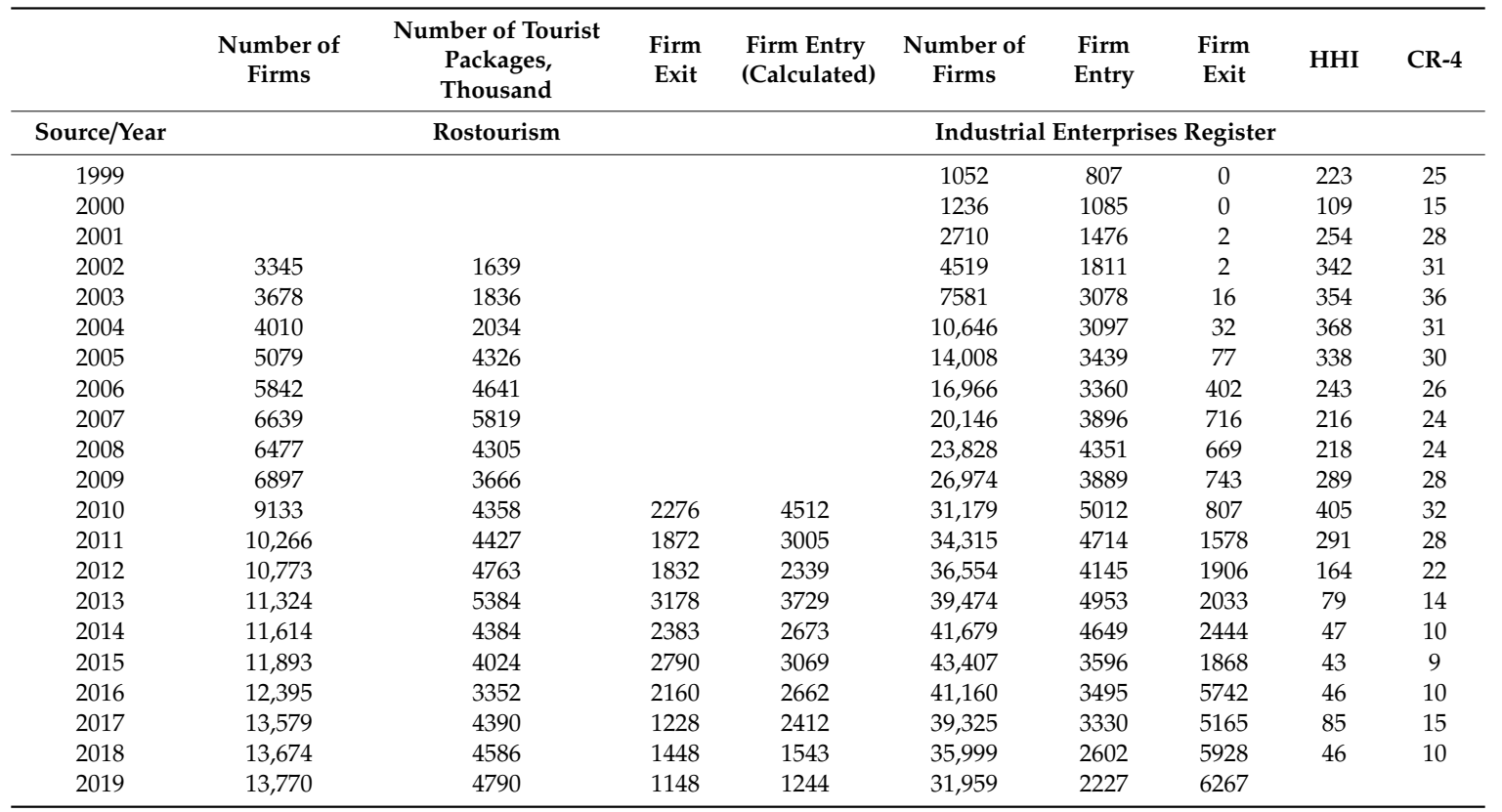

\section{Emergence and Development of Contemporary Tourism Industry in Russia}

In the Union of Soviet Socialist Republics (USSR), tourism was not considered as an economically significant industry (Gorsuch 2011). Tourism was not included in the state planning system, there was no special tourism legislation (Burns 1998; Chemakin 1984). The very concept of tourism was associated with sports and health promotion, and not with economic activities that can generate

1 SPARK is an abbreviation for System of Professional Analysis of Markets and Companies [Sistema Professional'nogo Analiza Rynkov $i$ Kompaniy $=$ SPARK $]$. 
profit. Mass domestic tourism prevailed, to a large extent with subsidies (Gorsuch 2003); there was no high-quality tourism infrastructure at the international level (Dimanche and Andrades 2015; Sheresheva and Kopiski 2016).

After the collapse of the USSR, since the end of 1991, tourism in the Russian Federation began to develop as a sphere of entrepreneurial activity. The emergence of the contemporary tourism industry in Russia led to the change in the position of the former monopolists Intourist, Sputnik, and the Central Council for Tourism and Excursions. They lost their monopoly on organizing foreign tourism and transformed into joint-stock companies and holdings. The number of private companies offering tourist services has grown rapidly, especially in the outbound tourism sector.

There were obvious positive changes in tourism infrastructure and transportation services. Foreign hotel chains entered the Russian market, bringing their quality standards (Balaeva et al. 2012; Sheresheva et al. 2018); the emergence of private airlines contributed to the further development of the competitive environment in the tourism industry. Important shifts have occurred in the system of state regulation, especially after the adoption in 1996 of the Federal Law "On the Basics of Tourism in the Russian Federation". Russian tourism statistics started to develop in 1998. The experience of Greece in organizing tourism statistical monitoring was taken as an example to follow. Since 2002, there was statistical monitoring of the travel agencies' and collective accommodation facilities activity.

The statistics confirm that the Russian tourism industry has shown steady development (Sheresheva and Kopiski 2016; Sheresheva 2018), though the dynamics were not stable (Gudkov et al. 2018). Moreover, there have been several crises on the demand side throughout the 30-year history of Russian tourism (Figure 2): the severe economic crisis in 1998, the fall in demand for tourism services against the backdrop of the global financial crisis in 2008-2009 and the crisis phenomena in 2014 due to geopolitical changes and sanctions (Sheresheva 2018). The negative impact of sanctions on Russian tourism is not so obvious, as the depreciation of the national currency contributed to the symmetrical expansion of domestic tourism (Ziganshin et al. 2015). Still, further research may show additional negative effects due to the lag effect of sanctions (Seyfi and Hall 2019, 2020).

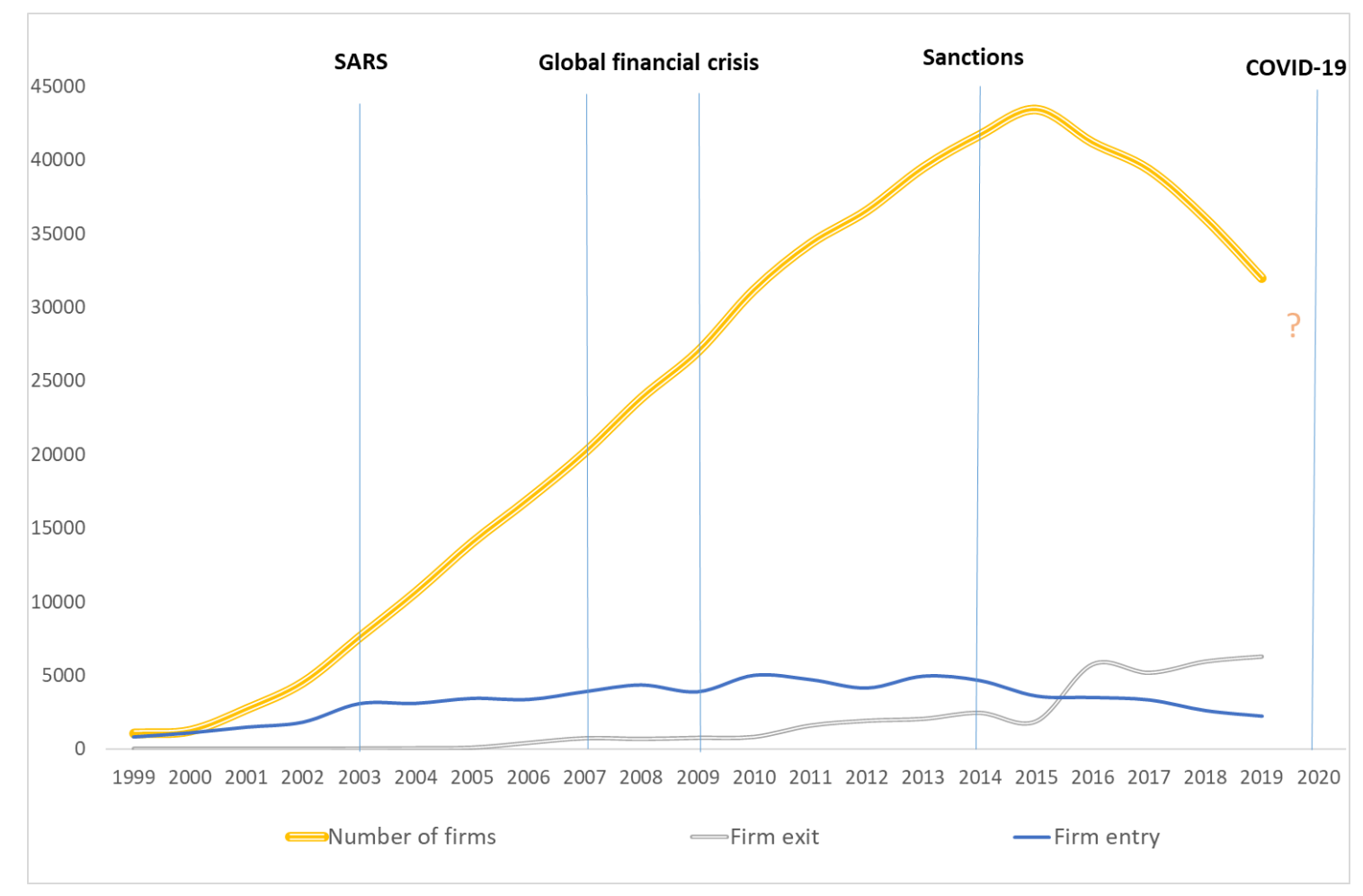

Figure 2. The dynamics of the Russian tourism industry (data from Industrial register). 
Due to the COVID-19 pandemic, the activity on the market almost stopped in 2020, like in the world tourism market as a whole. Still, there is obvious interest in tourism industry support in Russia, based on the understanding that such a multi-layered and complex industry as tourism may not be a burden, but a locomotive of the post-pandemic economic recovery (Sheresheva 2020). Understanding the industry dynamics may be important in assessing the effects of the state supportive measures in the near future and the long run.

\section{The Russian Tourism Industry Dynamics: Results and Discussion}

Analysis of the Russian tourism industry dynamics showed that the number of actors in the industry increased over the first $15-20$ years by almost $20 \%$ per year; this trend continued until 2015, when many factors on the demand side led to more than five thousand tour operators leaving the industry in 2016 (Gudkov et al. 2018). From this moment on, the number of firms that decided to exit from the market continues to increase while the number of newcomers is reducing. It is noteworthy that the global crisis did not have such a devastating effect on the Russian tourism sector as compared to the decrease in domestic solvent demand resulting from an almost double drop in the ruble exchange rate.

Of all the indicators describing changes in the Russian tourism market structure, "exit" is the most sensitive to exogenous factors, while the "entry" of new firms is determined by the industry margin and the size of administrative barriers. One must recognize that the attempt to describe the dynamics of the industry's structural characteristics using only the industry cycle stages has its limitations. Still, the similarity of the obtained picture with the schematic illustration made by Agarwal and Gort (Figure 1) suggests the commonality of the processes that regulate the population of firms in any industry.

Our comparison of Russian tourism industry dynamics with indicators of market concentration (HHI-score and CR\%) (Figure 3) allows us to conclude that a period of stabilization and enlargement of companies active in the market was observed at earlier stages of market development (until 2010). The decrease in the total number of firms coincide not with the increase in concentration, but with its decrease- this suggests that many large firms left the market during the crisis.

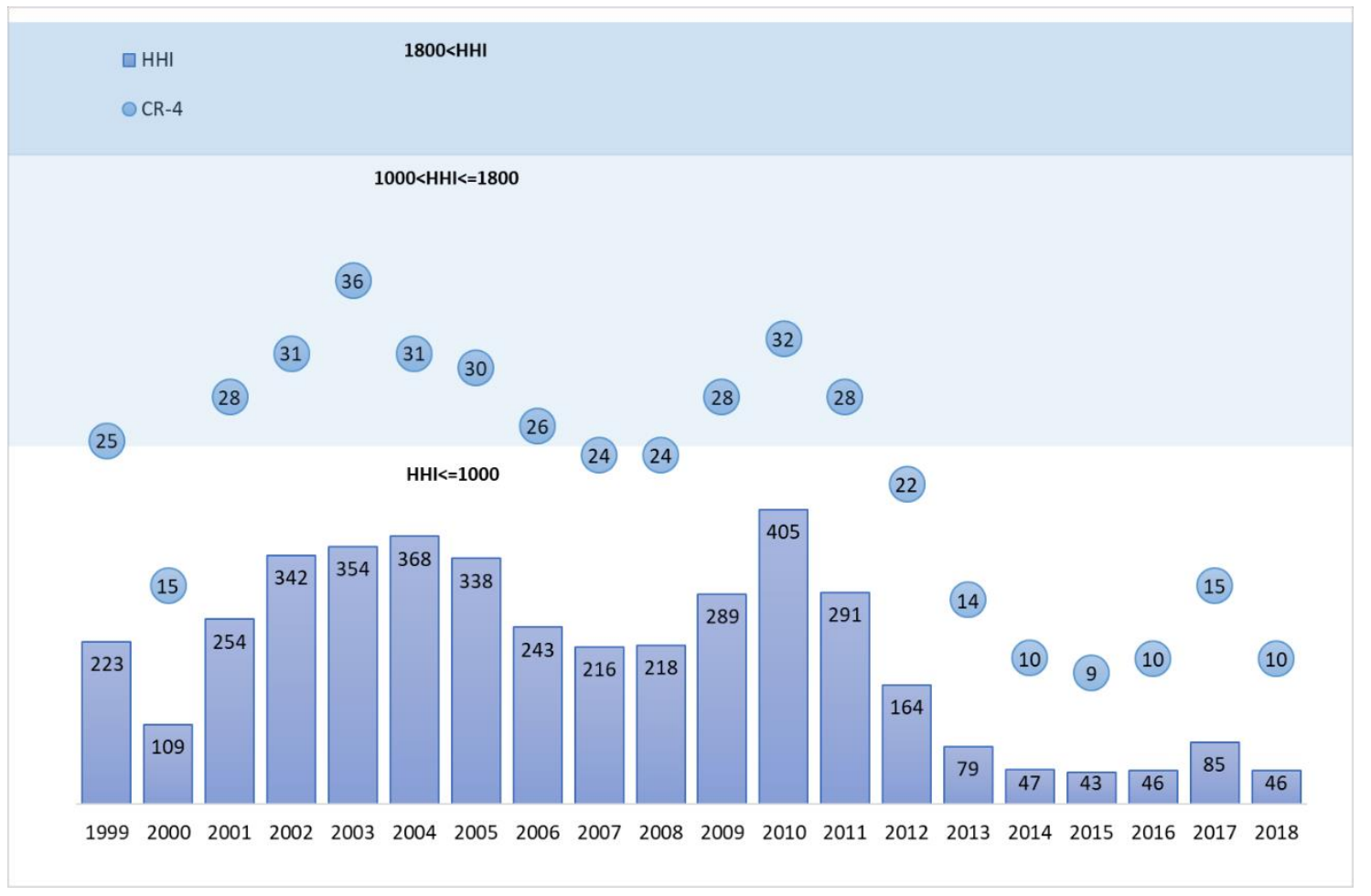

Figure 3. Russian tourism industry and Herfindahl-Hirschman Index (HHI). 
Determining the Russian tourism market concentration level (HHI-score) is complicated by the reluctance of many tourism operators to provide financial and economic information about themselves (especially in the early 2000s). If leaders in the most popular areas hesitate to disclose their data, ratings of the largest companies cease to be considered as reliable information sources. Judging by the data from the industrial enterprises register («Spark-Interfax»), the Russian tourism services market has never been a highly concentrated sector. The largest Herfindahl-Hirschman Index did not exceed 500, and the total share of industry revenue attributable to the four largest companies was about $30 \%$.

The obtained results show that along with the macroeconomic, market, demand characteristics external to the industry, microeconomic factors related to the evolutionary stage of the industry's life cycle can also influence the tourism industry dynamics.

\section{Conclusions}

Based on the results of the conducted study, we can make some concluding remarks.

The research contributes to the academic literature on tourism development in transition economies by highlighting the importance of microeconomic factors on the example of the Russian tourism market. While assessing the dynamics of the industry (both structural indicators related to the number of firms, and performance indicators like sales or profitability), it is important to consider not only the demand and macroeconomic indicators, which are external risks in relation to the industry, but also the internal processes that are different at the different stages of the product cycle. Along with the risk of declining solvent demand, administrative barriers, unfavorable international conditions, etc., there are economies of scale and scope, learning-by-doing, obsolescence of traditional technology, etc., changing the firms' size distribution in the tourism market and creating additional risks for the industry actors. If we consider a sufficiently long period, then the influence of microeconomic indicators that are "fundamental" for the industry dynamics, as well as economic cycles, may turn out to be no less strong than the business factors of financial risk. These considerations must be taken into account, for example, in econometric modeling on long time-series. To complete the picture, we need to develop some econometric or imitative model that would describe the change in the sectoral structure as a function of exogenous factors connected to demand, regulatory impact and macroeconomic conditions, and the endogenous characteristics of the industry evolution stages. Taking into account internal dynamics allows us to understand what this general trend looks like, and shows the limits of external impact.

The results can be also useful for state policy decision-makers in tourism. The successful revival of the tourism industry in the post-pandemic period will depend on the balanced practical measures based on the right combination of macro- and microeconomic indicators that comprehensively describe the market and the industry.

In this study, we did not aim to forecast industry development. Our focus was a descriptive analysis of possible determinants of tourism industry dynamics. At present, the biggest limitation for this kind of modeling is the great uncertainty associated with the adverse epidemiological situation, particularly tangible for the tourism industry. The impact of such a powerful external shock requires special scenario modeling of tourism development in the short and medium run.

Author Contributions: The authorship is limited to those who have equally contributed to the work reported. M.S. is responsible for conceptualization, methodology, supervision, formal analysis, validation, original draft, review \& editing; L.V. is responsible for methodology, resources, data curation, formal analysis, validation, and original draft; M.O. is responsible for conceptualization and original draft; M.T. is responsible for resources, software, formal analysis, and original draft. All authors have read and agreed to the published version of the manuscript.

Funding: This research received no external funding.

Conflicts of Interest: The authors declare no conflict of interest. 


\section{References}

Agarwal, Rajshree, and Michael Gort. 1996. The Evolution of Markets and Entry, Exit and Survival of Firms. The Review of Economics and Statistics 3: 489-98. Available online: https://pdfs.semanticscholar.org/be77/ 465aafcb967d57b7142211efea8edcedc0ac.pdf (accessed on 30 March 2020). [CrossRef]

Algieri, Bernardina. 2006. An econometric estimation of the demand for tourism: The case of Russia. Tourism Economics 1: 5-20. [CrossRef]

Amir, Rabah, and Natalia Lazzati. 2011. Network effects, market structure and industry performance. Journal of Economic Theory 6: 2389-419. Available online: https://papers.ssrn.com/sol3/papers.cfm?abstract_id=1499909 (accessed on 30 March 2020). [CrossRef]

Andrades, Lidia, and Frederic Dimanche. 2017. Destination competitiveness and tourism development in Russia: Issues and challenges. Tourism Management 62: 360-76. [CrossRef]

Armstrong, Mark, and Robert H. Porter, eds. 2007. Handbook of Industrial Organization. Amsterdam: Elsevier, Available online: https:/www.elsevier.com/books/handbook-of-industrial-organization/armstrong/978-0444-82435-6 (accessed on 30 March 2020).

Balaeva, Olga, Ella Burnatseva, Marina Predvoditeleva, Marina Sheresheva, and Olga Tretyak. 2012. Network strategies of hospitality companies in emerging and transitory economies: Evidence from Russia. In Service Science Research, Strategy and Innovation: Dynamic Knowledge Management Methods. Hershey: IGI Global, pp. 519-46. Available online: https://www.igi-global.com/gateway/chapter/61893 (accessed on 30 March 2020).

Baum, Tom. 1998. Taking the exit route: Extending the tourism area life cycle model. Current Issues in Tourism 1: 167-75. [CrossRef]

Brock, William, and Anastasios Xepapadeas. 2002. Optimal ecosystem management when species compete for limiting resources. Journal of Environmental Economics and Management 2: 189-220. Available online: https://econpapers.repec.org/paper/attwimass/200027.htm (accessed on 30 March 2020). [CrossRef]

Brouder, Patrick, and Rikard H. Eriksson. 2013. Staying power: What influences micro-firm survival in tourism? Tourism Geographies 1: 125-44. Available online: https://link.springer.com/article/10.1007/s12132-014-9239-z (accessed on 30 March 2020). [CrossRef]

Burns, Peter. 1998. Tourism in Russia: Background and structure. Tourism Management 6: 555-65. [CrossRef]

Butler, Richard W. 1980. The concept of a tourist area cycle of evolution: Implications for management of resources. Canadian Geographer/Le Géographe Canadien 24: 5-12. [CrossRef]

Butler, Richard W. 2006. The Tourism Area Life Cycle. Bristol: Channel View Publications, vols. 1 and 2.

Chemakin, I. M. 1984. Codification of Legislation on Physical Culture, Sports, and Tourism. Soviet Law and Government 3: 73-89. [CrossRef]

Chkalova, Olga, Marina Efremova, Vladimir Lezhnin, Anna Polukhina, and Marina Sheresheva. 2019. Innovative mechanism for local tourism system management: A case study. Entrepreneurship and Sustainability Issues 4: 2052-67. Available online: https://www.jssidoi.org/jesi/uploads/articles/24/Chkalova_ Innovative_mechanism_for_local_tourism_system_management_a_case_study.pdf (accessed on 30 March 2020). [CrossRef]

Clementi, Gian Luca, and Berardino Palazzo. 2016. Entry, exit, firm dynamics, and aggregate fluctuations. American Economic Journal: Macroeconomics 3: 1-41. Available online: http://pages.stern.nyu.edu/ \{\}gclement/ Papers/Entry_exit.pdf (accessed on 30 March 2020). [CrossRef]

Dimanche, Frédéric, and Lidia Andrades, eds. 2015. Tourism in Russia: A Management Handbook. Bingley: Emerald Group Publishing, Available online: https://www.researchgate.net/publication/280094297_Tourism_ in_Russia_A_Management_Handbook (accessed on 30 March 2020).

Dosi, Giovanni, and Richard R. Nelson. 2010. Technical change and industrial dynamics as evolutionary processes. In Handbook of the Economics of Innovation. North-Holland: Elsevier, vol. 1, pp. 51-127. [CrossRef]

Fernandes, Paula Odete, Alcina Maria Nunes, Cláudia Miranda Veloso, Eleonora Santos, Fernanda A. Ferreira, and Manuel José Fonseca. 2020. Spatial and temporal concentration of tourism supply and demand in Northern Portugal. Application of the Herfindahl-Hirschman index. In Advances in Tourism, Technology and Smart Systems. Singapore: Springer, pp. 263-73. 
Foster, Richard, and Sarah Kaplan. 2001. Creative Destruction: Why Companies That Are Built to Last Underperform the Market—and How to Successfully Transform Them. New York: Currency/Doubleday, Available online: https://www.pdfdrive.com/creative-destruction-why-companies-that-are-built-tolast-underperform-the-market-and-how-to-successfully-transform-them-e194520467.html (accessed on 30 March 2020).

Freiling, Jörg, and Thomas Baron. 2017. A resource-based view of entrepreneurial ecosystems. In Technologie, Strategie und Organisation. Wiesbaden: Springer Gabler, pp. 65-84. Available online: https://link.springer. com/chapter/10.1007\%2F978-3-658-16042-5_4 (accessed on 30 March 2020).

Frenken, Koen, Elena Cefis, and Erik Stam. 2015. Industrial dynamics and clusters: A survey. Regional Studies 1: 10-27. [CrossRef]

Frolova, Elena Victorovna, Tatyana Mikhailovna Ryabova, Elena Evgen'evna Kabanova, Olga Vladimirovna Rogach, and Ekaterina Alexandrovna Vetrova. 2017. Domestic tourism in Russian Federation: Population estimations, resources and development constraints. Journal of Environmental Management and Tourism 2: 436-45. Available online: https://www.elibrary.ru/item.asp?id=29402213 (accessed on 30 March 2020).

Garay, Luis, and Gemma Cánoves. 2011. Life cycles, stages and tourism history: The Catalonia (Spain) experience. Annals of Tourism Research 2: 651-71. [CrossRef]

Gorsuch, Anne E. 2003. “There's No Place Like Home”: Soviet Tourism in Late Stalinism. Slavic Review 4: 760-85. [CrossRef]

Gorsuch, Anne E. 2011. All This Is Your World: Soviet Tourism at Home and Abroad after Stalin. Oxford: OUP, Available online: https://www.cambridge.org/core/journals/annales-histoire-sciences-sociales/article/ anne-e-gorsuch-all-this-is-your-world-soviet-tourism-at-home-and-abroad-after-stalin-oxford-oxforduniversity-press-2011-222-p/640287C3382B91CD3647F19945CFB4C0 (accessed on 30 March 2020).

Gort, Michael, and Steven Klepper. 1982. Time paths in the diffusion of product innovations. The Economic Journal 92: 630-53. Available online: https://ideas.repec.org/a/ecj/econjl/v92y1982i367p630-53.html (accessed on 30 March 2020). [CrossRef]

Gudkov, Alexander, Elena Dedkova, and Kristina Dudina. 2018. The Main Trends in the Russian Tourism and Hospitality Market from the Point of View of Russian Travel Agencies. Worldwide Hospitality and Tourism Themes. [CrossRef]

Javid, Elyeh, and Salih Katircioglu. 2017. The globalization indicators-tourism development nexus: A dynamic panel-data analysis. Asia Pacific Journal of Tourism Research 11: 1194-205. [CrossRef]

Jawahar, I. M., and Gary L. McLaughlin. 2001. Toward a descriptive stakeholder theory: An organizational life cycle approach. Academy of Management Review 3: 397-414. Available online: https://www.jstor.org/stable/259184 (accessed on 30 March 2020). [CrossRef]

Jelili, Riadh Ben, and Mohamed Goaied. 2010. Entry, exit, and productivity in Tunisian manufacturing industries. In Market Dynamics and Productivity in Developing Countries. New York: Springer, pp. 73-108. Available online: https://link.springer.com/chapter/10.1007/978-1-4419-1037-0_4 (accessed on 30 March 2020).

Klepper, Steven. 1997. Industry life cycles. Industrial and Corporate Change 1: 145-82. Available online: https://ideas.repec.org/a/oup/indcch/v6y1997i1p145-81.html (accessed on 30 March 2020). [CrossRef]

Koenker, Diane P. 2003. Travel to work, travel to play: On Russian tourism, travel, and leisure. Slavic Review 4: 657-65. Available online: https://www.cambridge.org/core/journals/slavic-review/article/travel-to-worktravel-to-play-on-russian-tourism-travel-and-leisure/35AE05321649AFB83C202868F1B617EF (accessed on 30 March 2020). [CrossRef]

Lábaj, Martin, Karol Morvay, Peter Silanič, Christoph Weiss, and Biliana Yontcheva. 2018. Market structure and competition in transition: results from a spatial analysis. Applied Economics 15: 1694-715. [CrossRef]

Lagiewski, Rchard M. 2006. The application of the TALC model: A literature survey. The Tourism Area Life Cycle 1: 27-50.

Lester, Donald L., John Alan Parnell, and Shawn M. Carraher. 2003. Organizational life cycle: A five-stage empirical scale. The International Journal of Organizational Analysis 4: 339-54. [CrossRef]

Massidda, Carla, and Ivan Etzo. 2012. The determinants of Italian domestic tourism: A panel data analysis. Tourism Management 3: 603-10. [CrossRef]

Morley, Clive, Jaume Rosselló, and Maria Santana-Gallego. 2014. Gravity models for tourism demand: theory and use. Annals of Tourism Research 48: 1-10. [CrossRef] 
Peltoniemi, Mirva. 2011. Reviewing industry life-cycle theory: Avenues for future research. International Journal of Management Reviews 4: 349-75. [CrossRef]

Petković, Goran, Stipe Lovreta, Renata Pindžo, and Saša Pešić. 2016. Evaluating the concentration in Serbian tourism and FMCG retail sector. Ekonomika Preduzeća 1-2: 187-98. [CrossRef]

Quinn, Robert E., and Kim Cameron. 1983. Organizational life cycles and shifting criteria of effectiveness: Some preliminary evidence. Management Science 1: 33-51. [CrossRef]

Scott, Anthony D., Patrick S. Viguerie, Evan I. Schwartz, and John Van Landeghem. 2018. Corporate Longevity Forecast: Creative Destruction Is Accelerating. Lexington: Innosight, Available online: https://www.innosight. com/wp-content/uploads/2017/11/Innosight-Corporate-Longevity-2018.pdf (accessed on 30 March 2020).

Seyfi, Siamak, and Michael C. Hall. 2019. International sanctions, tourism destinations and resistive economy. Journal of Policy Research in Tourism, Leisure and Events 11: 159-69. [CrossRef]

Seyfi, Siamak, and Michael C. Hall. 2020. Sanctions and tourism: conceptualisation and implications for destination marketing and management. Journal of Destination Marketing Management 15. [CrossRef]

Sheresheva, Marina Y. 2018. The Russian tourism and hospitality market: New challenges and destinations. Worldwide Hospitality and Tourism Themes 4: 400-11. [CrossRef]

Sheresheva, Marina Y. 2020. Coronavirus and tourism. Population and Economics 2: 72-76. [CrossRef]

Sheresheva, Marina Y., and John Kopiski. 2016. The main trends, challenges and success factors in the Russian hospitality and tourism market. Worldwide Hospitality and Tourism Themes 3: 260-72. [CrossRef]

Sheresheva, Marina Y., Matvey S. Oborin, and Elena E. Polyanskaya. 2018. International hotel chains in Russia: The prospects and challenges of movement from megacities to smaller cities in Russian regions. Worldwide Hospitality and Tourism Themes 4: 421-35. [CrossRef]

Soh, Ann-Ni, Chin-Hong Puah, and Arip Mohammad Affendy. 2019. Construction of tourism cycle indicator: A signalling tool for tourism market dynamics. Electronic Journal of Applied Statistical Analysis 2: 477-90. Available online: http://siba-ese.unisalento.it/index.php/ejasa/article/view/20164 (accessed on 30 March 2020).

Song, Haiyan, Larry Dwyer, Gang Li, and Zheng Cao. 2012. Tourism economics research: A review and assessment. Annals of Tourism Research 3: 1653-82. [CrossRef]

Stabler, Mike J., Andreas Papatheodorou, and M. Thea Sinclair. 2009. The Economics of Tourism. London: Taylor \& Francis.

Zaitseva, Natalia A., Elena G. Kropinova, Valentin S. Korneevets, Irina I. Dragileva, and Alexey D. Chudnovskiy. 2016. The long-term forecast of the Russian tourism development. International Review of Management and Marketing 6: 103-10. Available online: https://www.researchgate.net/publication/306229903_The_LongTerm_Forecast_of_the_Russian_Tourism_Development (accessed on 30 March 2020).

Ziganshin, Irek I., Anton O. Ovcharov, and Marina A. Rysayeva. 2015. Influence of economic sanctions on the development of Russian tourism. Aktual'niye Problemy Ekonomiki i Prava 1: 17-25. Available online: https://www.researchgate.net/publication/307770542_Influence_of_economic_sanctions_on_the_ development_of_Russian_tourism (accessed on 30 March 2020).

(C) 2020 by the authors. Licensee MDPI, Basel, Switzerland. This article is an open access article distributed under the terms and conditions of the Creative Commons Attribution (CC BY) license (http://creativecommons.org/licenses/by/4.0/). 